\title{
Partisipasi Masyarakat dalam Perencanaan Teritorial (Studi Komparasi: Borobudur dan Nantes)
}

\author{
Reny Agustine Nur Adhanani ${ }^{1}$
}

Diterima : 4 September 2013

Disetujui : 19 September 2013

\begin{abstract}
The issue of public participation in spatial planning has become a topic of debate in many parts of the world in recent decades, as well as in Indonesia and France. Indonesia put its effort to manifest the idea of public participation through the institutionalized annual program namely Musrenbang since 2004. In spite of numerous critics addressed, the program remains for nearly a decade without any significant improvement. Whilst, the presence of the organization "Peta Hijau", despite its very limited resources, had succeeded inviting the citizens to be involved in a mapping project in the village of Borobudur. In different scale and situation, the city of Nantes with its "Dialogue Citoyen" successfully bridged the citizens and the decision makers in the process of coproduction the public policy in territorial planning since 2010. Taking a lesson learn from the practice in Borobudur and Nantes, the non technical aspect such as a strong commitment and trust building capability are ones of the key to properly bring the concept of citizen participation into reality.
\end{abstract}

Keywords: citizen participation, territorial planning, decision making, development social

\section{ABSTRAK}

Gagasan tentang partisipasi masyarakat dalam perencanaan teritorial menjadi isu yang diperdebatkan di berbagai negara dalam beberapa dekade terakhir, seperti juga di Indonesia dan Perancis. Indonesia berupaya untuk sepenuhnya mewujudkan konsep partisipasi masyarakat melalui program institusional Musrenbang. Walaupun banyak kritik yang diterima, program tersebut terus dilaksanakan selama hampir satu dekade tanpa mengalami perbaikan signifikan dalam pelaksanaannya. Di sisi lain, komunitas Peta Hijau berhasil mengajak warga lokal untuk berpartisipasi dalam kegiatan pemetaan bersama walaupun dengan sumber daya yang sangat terbatas. Dalam skala dan situasi yang berbeda, Kota Nantes di Perancis dengan program Dialog Warga berhasil menjembatani pihak masyarakat dengan pihak pengambil keputusan dalam proses penyusunan bersama kebijakan publik dalam perencanaan teritorial. Mengambil pembelajaran dari Borobudur dan Nantes, aspek non teknis seperti komitmen yang kuat dan kemampuan membangun kepercayaan merupakan faktor kunci untuk dapat menerapkan konsep partisipasi masyarakat secara optimal.

Kata kunci: partisipasi masyarakat, perencanaan teritorial, pembangunan sosial

\footnotetext{
${ }^{1}$ Mahasiswa Magister Pembangunan Wilayah dan Kota, Undip, Semarang, Jawa Tengah Kontak Penulis : renyagustine@gmail.com
} 


\section{PENDAHULUAN}

Partisipasi masyarakat dapat diartikan sebagai sebuah proses yang didalamnya terdapat masyarakat umum yang mengambil bagian dalam pengambilan keputusan, baik sebagai individu maupun atas nama perkumpulan atau asosiasi (André, 2012). Partisipasi melibatkan usaha yang dilakukan untuk membuat orang mengetahui dengan baik hak-haknya untuk berkontribusi dalam pengambilan keputusan serta menyediakan akses terhadap informasi yang berkaitan dengan proses pengambilan keputusan yang mempengaruhi publik (UK Department for International Development, 2005 dalam Hemmati. dir, 2007 ; p.13). Ide untuk melibatkan warga ini berkembang seiring dengan adanya pergeseran sistem pemerintahan di negara-negara demokrasi dari sistem sentralisasi menjadi desentralisasi di abad 20-an yang memungkinkan warga untuk memiliki ruang yang lebih luas untuk mengekspresikan pendapatnya.

Penelitian ini membatasi pembahasan mengenai partisipasi masyarakat dalam perencanaan teritorial atas pertimbangan bahwa hal ini merepresentasikan tahapan fundamental sebagai dasar pengambilan tindakan untuk proses selanjutnya. Perencanaan terdiri dari serangkaian tindakan berurutan yang mengarah ke perwujudan tujuan utama (Hall, 1992 ; p.3 dan Johnson et al., 1981 dalam Chauduri, 2001; p.29). Proses perencanaan melibatkan beberapa kegiatan tertentu, diawali dari identifikasi permasalahan di lapangan (Glasson, 1975; p.5). Oleh karenanya, penting untuk mengikutsertakan warga untuk memahami dengan baik permasalahan yang dihadapi di wilayah perencanaan sebelum memulai proses pembangunan. Dalam konteks perencanaan teritorial tersebut, Amerika Serikat adalah yang pertama kali menggunakan terminologi partisipasi masyarakat dalam sebuah program peremajaan kota di tahun 1950-an (André, 2012).

Partisipasi masyarakat juga menegaskan spirit yang terkandung dalam konsep pembangunan berkelanjutan yang secara perlahan namun pasti menggantikan konsep klasik pembangunan yang lebih menitikberatkan orientasinya pada pertumbuhan ekonomi (Rostow 1960 dalam Baker, 2006 ; p.2). Pada dasarnya, "keberlanjutan" merupakan keluaran dari konsep ekologi, dan dengan menambahkan konsep "pembangunan" maka focus pembahasan bergeser dari lingkungan ke masyarakat (Baker, 2006; p. 7). Berkaitan dengan hal tersebut, warga merupakan entitas penting dari suatu wilayah dan tidak dapat diabaikan atau diperlakukan hanya sebagai obyek pembangunan, melainkan juga sebagai pelaksana dalam proses secara keseluruhan (Tournon, dir., 2009 ; p.90). Dengan terlibatnya warga, akan ada pembangunan masyarakat melalui transfer pengetahuan dari para ahli [pengambil keputusan dan mereka yang memfasilitasi terjadinya partisipasi] ke masyarakat awam [warga] (Verdier, 2009; p.11, Ergazakis et al., 2004 dalam Goldberg et al., 2006 ; p.93).

Dalam realitasnya, partisipasi masyarakat di negara berkembang berdasarkan tangga partisipasi Arnstein pada umumnya terletak di tingkatan bawah. Demikian halnya di Indonesia, sebelum era reformasi di tahun 1998, penerapan partisipasi masyarakat terletak di anak tangga terbawah atau bahkan tidak ada sama sekali. Pemerintah menggunakan mekanisme top-down dengan dominasi kekuasaan dan kontrol dari pusat pada semua aspek pembangunan. Paska era reformasi, pemerintahan yang baru bertekad untuk menghidupkan transparansi dan kebebasan berpendapat serta memasukkan konsep partisipasi masyarakat dalam konstitusi. Disposisi resmi untuk pelibatan masyarakat dalam pengambilan keputusan pembangunan dilakukan melalui program tahunan Musyawarah Perencanaan Pembangunan yang didasarkan pada Undang-undang Nomor 25 Tahun 2004 tentang Sistem Perencanaan dan Pembangunan Nasional dan Undang-undang Nomor 32 Tahun 2004 tentang Pemerintahan Regional. 
Diselenggarakan hampir satu dekade, program tersebut masih terus menuai banyak kritik dari berbagai pihak (Waspada News, 4 April 2011).

Di samping program institusional, terdapat organisasi non pemerintah yang giat melakukan kegiatan bersama warga berkaitan dengan isu-isu perkotaan. Komunitas Peta Hijau, bagian dari jaringan internasional Greenmap, adalah salah satu organisasi tersebut. Dengan metodenya "membuat peta bersama warga", organisasi ini berkeinginan untuk dapat meningkatkan kesadaran dan pemahaman warga pada isu-isu yang berkaitan dengan lingkungan tempat tinggalnya. Misi utama dari organisasi ini adalah untuk mengubah perilaku masyarakat sehingga mereka dapat berkontribusi dalam menjaga kondisi lingkungan.

Telah berdiri di berbagai kota di Indonesia sejak 1992, komunitas Peta Hijau Yogyakarta menjadi salah satu yang paling aktif bahkan di jaringan global. Lebih lanjut, berdasarkan anggota komunitas yang diwawancara bulan Juli 2012, "Peta Hijau Mandala Borobudur" sejauh ini merupakan proyek pemetaan yang dinilai paling berhasil dalam hal pelibatan masyarakat. Proses pemetaan bersama yang diselesaikan pada tahun 2009 tersebut bermanfaat sebagai media untuk mengetahui potensi dan permasalahan di Desa Borobudur secara menyeluruh. Kompleksitas sebagai akibat dari ragam kepentingan wisata dan sejarah serta kebijakan dari tingkat nasional untuk kawasan Borobudur semakin menambah nilai keberhasilan kegiatan pemetaan tersebut.

Dalam skala dan situasi yang berbeda, Kota Nantes di Perancis memberikan perhatian khusus untuk penerapan partisipasi warga dalam proses perencanaan dan pembangunan. Pada awalnya, partisipasi publik dilakukan melalui wewenang badan bernama Comité Consultatif de Quartier (CCQ) yang bertanggung jawab untuk membangun komunikasi yang baik dengan warga sebagai kanal komunikasi yang dekat dan mudah dicapai (proximity communication). Selanjutnya, CCQ digantikan oleh Conseil de Quartier (CQ) sebagai perantara untuk memperkuat peran dan komitmen pemerintah kota dalam membangun dialog dengan warga. Selain itu, CQ memiliki fokus untuk mencari masukan dan solusi dari masyarakat untuk kebijakan publik dan juga program-program pembangunan perkotaan dan sosial yang dilakukan di lingkungannya [sumber: Le Cahier d'Evaluation/ Buletin Evaluasi, November 2012].

Dalam proses realisasinya, Nantes berupaya untuk memperkuat praktek partisipasi publik melalui peresmian masa jabatan CQ yang pertama untuk periode 2010-2012 serta memulai pelaksanaan atelier citoyen/ lokakarya warga sebagai bagian dari program yang disebut Dialogue Citoyen atau "Dialog Warga". Lokakarya warga terbuka untuk umum dan dilakukan dengan menggunakan berbagai tema yang sudah dibahas dan ditentukan sebelumnya di sidang pleno. Tema yang dibahas bisa berkaitan dengan isu-isu yang dihadapi untuk peningkatan pelayanan publik secara umum atau hal-hal yang menyangkut kelompok masyarakat tertentu misalnya warga pendatang, warga lanjut usia, atau remaja. Di akhir sesi pertemuan, lokakarya warga menghasilkan sebuah dokumen Avis Citoyen atau "Opini Warga", yang memuat diagnosa permasalahan sekaligus rekomendasi solusi yang diusulkan untuk menjadi kebijakan publik di masa mendatang.

Penelitian ini bertujuan untuk melihat dan membandingkan praktek partisipatif di Borobudur dan di Nantes, untuk menjelaskan tentang tingkatan partisipasi warga, peran aktor yang terlibat, dan faktor-faktor yang bermanfaat dalam mendorong warga untuk turut mengambil bagian dan berpartisipasi dalam proses peningkatan kualitas lingkungan. Seluruh kegiatan observasi dan analisis yang dilakukan diarahkan degan tujuan untuk menjawab pertanyaan 
penelitian "bagaimanakah pendekatan yang dapat diterapkan untuk meningkatkan pelibatan warga dalam proses perencanaan ?”

\section{METODE PENELITIAN}

Metode yang digunakan dalam penelitian ini adalah eksplorasi untuk menggali dan menjelaskan dengan baik suatu fenomena yang terjadi (Marshall dan Rossman dalam Schneider, 2007) khususnya berkaitan dengan pelaksanaan partisipasi masyarakat di Borobudur dan Nantes. Pengumpulan data dilakukan melalui studi literatur, dokumen pelaksanaan kegiatan Peta Hijau dan program Dialogue Citoyen, serta wawancara dengan narasumber kunci di kedua lokasi. Teknik analisis yang digunakan dalam penelitian ini terdiri dari analisis deskriptif dan analisis komparasi. Kerangka analisis dalam penelitian ini dapat dilihat pada Gambar 1.

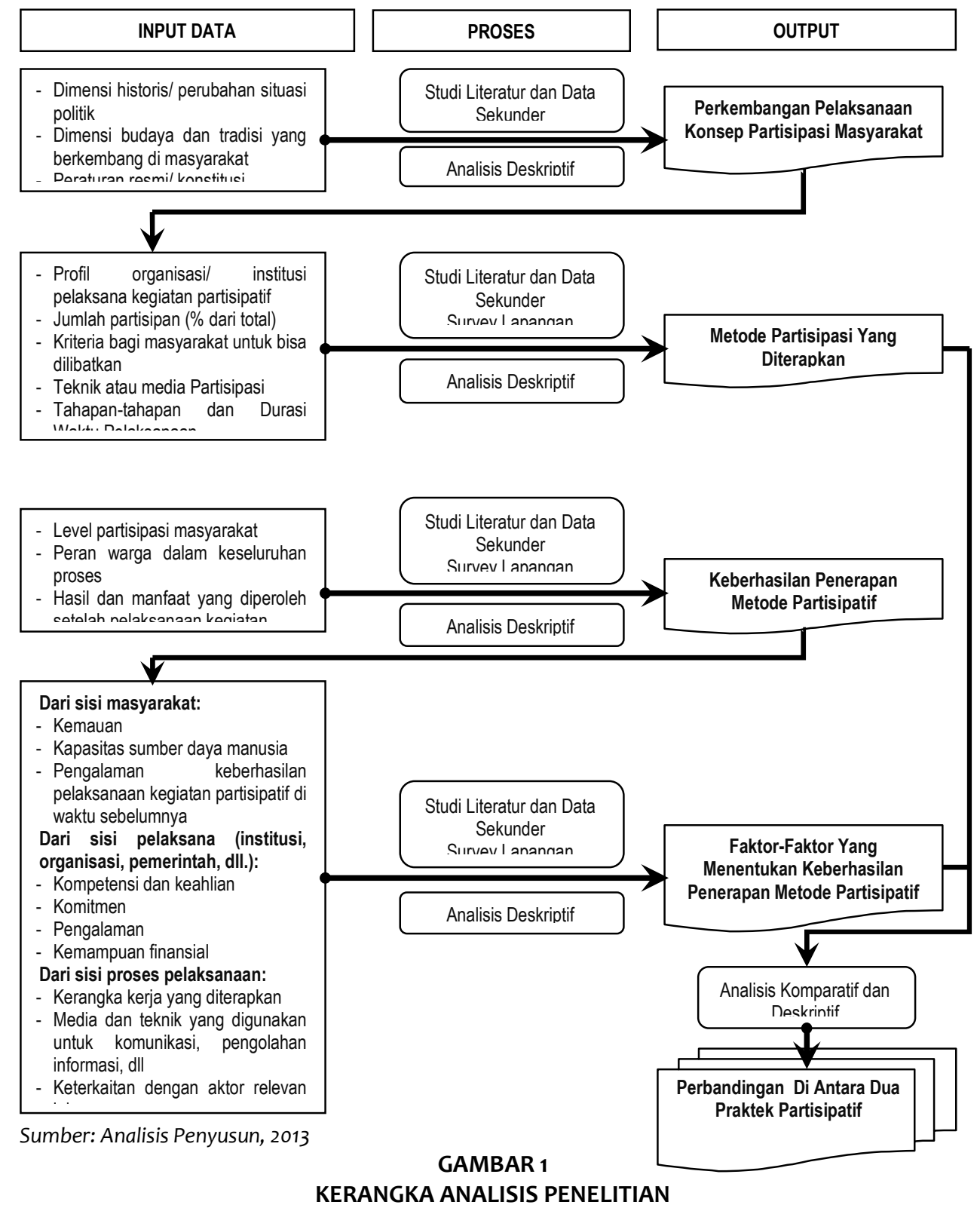




\section{ANALISIS}

\section{Upaya Penerapan Partisipasi Masyarakat di Indonesia}

Akar pelaksanaan konsep partisipasi masyarakat pada awalnya ditanamkan pada tahun 1998 ketika era reformasi bergulir. Sebelumnya, selama 32 tahun masa kepemimpinan Suharto, untuk menjaga stabilitas politik pemerintah pusat memberikan kontrol penuh untuk berbagai aspek pembangunan. Melalui pengesahan Undang-undang Nomor 22 tahun 1999 tentang Kewenangan Pemerintah Daerah yang mendukung transisi menuju desentralisasi menyatakan adanya pembagian kekuasaan dengan pemerintah setempat dalam perencanaan daerah serta menggarisbawahi pentingnya prinsip demokrasi dan pelibatan masyarakat dalam pembangunan.

Pada tahun 2004, pemerintah Indonesia mengesahkan Undang-Undang No 32 tentang Otonomi Daerah yang menyatakan mengenai pembagian wewenang pada tingkat desa untuk mengelola teritorialnya sebagai perwujudan dari pembangunan dari bawah ke atas (bottom-up planning). Hal tersebut direalisasikan melalui pelaksanaan Musyawarah Perencanaan Pembangunan di bawah wewenang Badan Pembangunan Daerah/Kota yang secara langsung bertanggung jawab pada Walikota/Bupati. Banyak publikasi dan kritik yang menyampaikan kegagalan forum Musrenbang yang sudah ada sejak hampir satu dekade. Salah satunya adalah harian "Waspada News" yang memuat hasil observasi pelaksanaan Musrenbang di Medan tahun 2011 dan menyebutnya sebagai kegiatan formalitas yang hanya menghasilkan daftar belanja tanpa benar-benar mengupayakan diskusi untuk mencari solusi untuk kondisi yang lebih baik.

Sementara itu, dilatarbelakangi oleh misi mengubah pemahaman dan perilaku masyarakat lokal terhadap pengelolaan lingkungan, komunitas Peta Hijau Yogyakarta giat melakukan kegiatan pemetaan tematik dengan melibatkan warga di area yang dipetakan. Dalam proses pemetaan yang dilakukan juga meliputi kegiatan mengdentifikasi dan mengeksplorasi potensi dan permasalahan pada zona pemetaan sesuai dengan tema peta yang disepakati. Kegiatan pemetaan yang dianggap berhasil mencapai misi organisasi tersebut adalah Peta Hijau Mandala Borobudur yang diinisiasi pada tahun 2006. Terlepas dari kompleksitas berbagai kebijakan nasional yang diterapkan untuk kawasan Candi Borobudur dan keterbatasan sumber daya yang dimiliki, komunitas Peta Hijau bersama relawan dan warga lokal berhasil menyelesaikan peta tersebut pada tahun 2009.

Berdasarkan wawancara yang dilakukan terhadap anggota komunitas dan warga lokal yang berpartisipasi dalam kegiatan pemetaan tersebut, tertangkap skeptisme yang besar untuk bekerja sama atau berkontribusi pada program-program pemerintah. Ketua tim kegiatan pemetaan dari Peta Hijau, Inu, menyatakan bahwa sebagian besar kebijakan pemerintah hanya memperlakukan Candi Borobudur sebagai monumen tunggal tanpa mempertimbangkan kondisi disekitarnya. Keberadaan Candi Borobudur sebagai magnet wisatawan hingga level internasional tidak lantas membawa kesejahteraan bagi masyarakat di sekitarnya, justru di sisi lain berbagai pembangunan yang dilakukan mengancam ekosistem lingkungan yang ada di Desa Borobudur. Penetapan Borobudur sebagai Kawasan Strategis Nasional melalui Peraturan No. 26 tahun 2008 dalam Rencana Tata Ruang Wilayah Nasional juga dinilai Inu hanya sebagai bagian dari kepentingan elit politik di tingkat nasional.

Selain itu, proses pembangunan yang dilakukan oleh PT Taman Wisata sebagai pengelola resmi area Candi Borobudur sejak tahun 1992 dinilai kurang mempertimbangkan dampak sosial dan lingkungan yang terjadi di kemudian hari. Kekecawaan seorang warga lokal bahkan 
membuatnya membenarkan "tindakan ilegal" yang dilakukan oleh sebagian warga desa yaitu melompati pagar area candi. Seperti diungkapkan dalam wawancara, hal tersebut dianggap sebagai tindakan yang lazim mengingat rute tersebut adalah jalur yang biasa dilewati masyarakat lokal sehari-hari sebelum PT Taman Wisata melakukan pembangunan area candi. Berbagai kekecewaan terhadap kebijakan pemerintah tersebut membuat masyarakat enggan berpartisipasi dalam program yang diterapkan di Desa Borobudur.

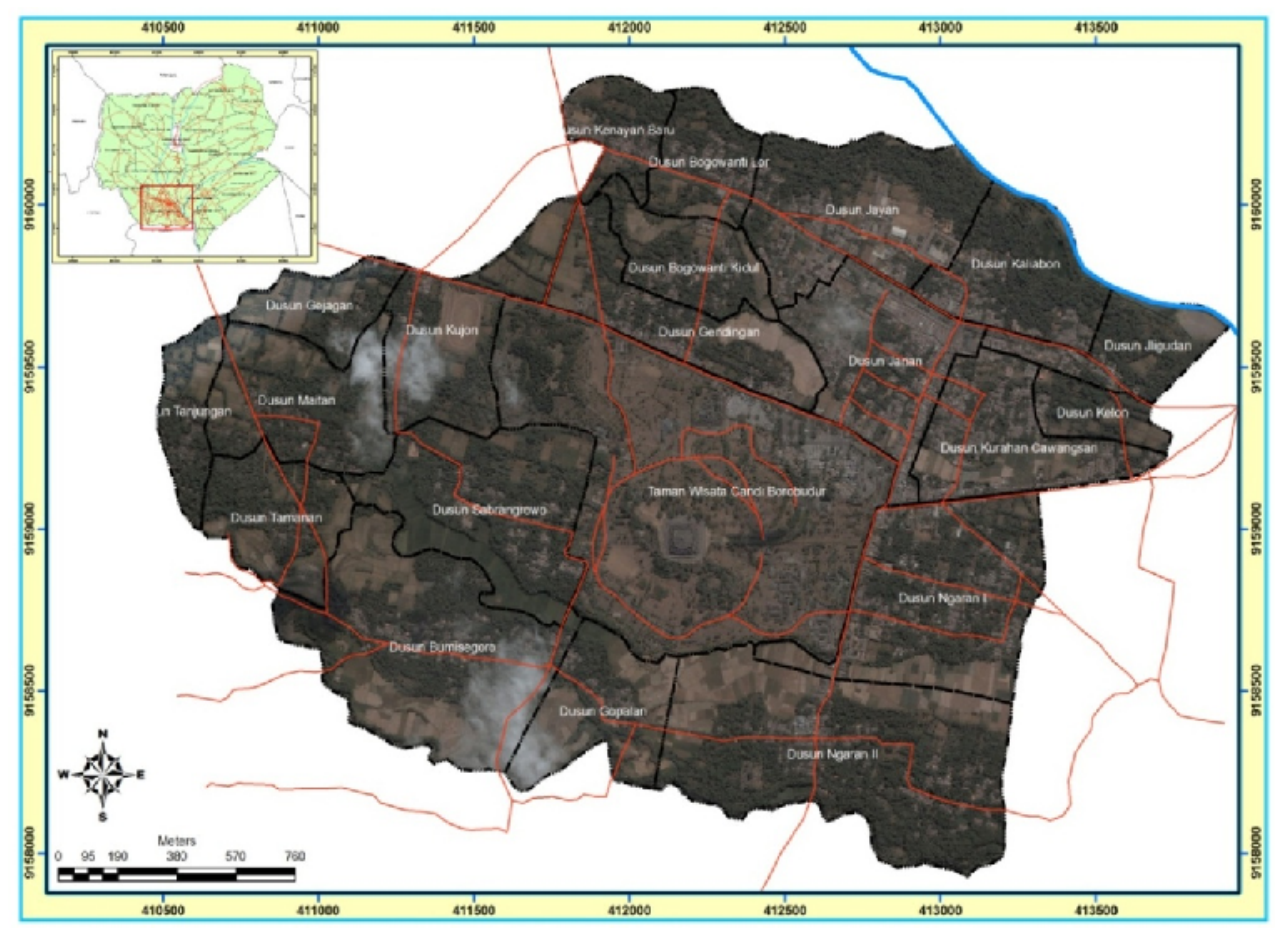

Sumber: Peta Dasar Kabupaten Magelang Skala 1:25.000 dan Google Earth, 2013

GAMBAR 2

WILAYAH ADMINISTRASI DESA BOROBUDUR

Namun, kehadiran Peta Hijau dengan metode pemetaan bersama berhasil menarik masyarakat lokal, khususnya para pemuda untuk ikut berpartisipasi. Pendekatan non formal dengan teknik komunikasi yang mudah dipahami oleh masyarakat umum membuat komunitas ini mendapatkan kepercayaan dari masyarakat setempat. Bahkan masyarakat lokal mengagumi komitmen yang tinggi dari para anggota komunitas yang melakukan kegiatan pemetaan secara sukarela. Tidak hanya memproduksi peta, kegiatan ini juga merupakan proses pendataan dan pendokumentasian bersama informasi sejarah desa, tradisi lokal, potensi dan permasalahan, serta perkembangan kondisi lingkungan Desa Borobudur. Lebih lanjut, hasil dari kegiatan ini diintegrasikan dalam Rencana Pembangunan Desa Borobudur dan menjadi embrio pengembangan SIG Desa Borobudur di kemudian hari.

\section{Komitmen Nantes untuk Melibatkan Masyarakat dalam Perencanaan}

Partisipasi masyarakat juga menjadi salah satu fokus perhatian pemerintah daerah di Perancis. Terminologi yang kerap digunakan di Perancis adalah "demokrasi partisipatif" dengan esensi dasar melibatkan masyarakat untuk berpartisipasi dalam proses pengambilan keputusan kebijakan. Lebih tepatnya, prinsip utama dari demokrasi partisipatif adalah proximity democracy yang menawarkan kesempatan yang sama kepada masyarakat untuk ikut menyuarakan pendapatnya (Le Galic, 2004). Walaupun pembahasan mengenai implementasi 
nyata dari demokrasi partisipatif berlangsung hingga sekarang, namun transformasi yang terjadi dapat diamati dengan jelas.

Kota Nantes, terletak di bagian barat Perancis, menunjukkan perkembangan yang menarik dalam upayanya melibatkan masyarakat dalam pengambilan keputusan. Pengalaman pertama dilakukan pada tahun 1989 melalui penyebaran angket untuk menjaring aspirasi masyarakat dalam rangka pengembangan jalur tram dalam kota. Setelah itu, Nantes terus berevolusi dalam upayanya menerapkan partisipasi masyarakat melalui pengesahan peraturan, pembentukan institusi yang berwenang, serta pelaksanaan program-program partisipatif.

Cikal bakal peraturan mengenai kebijakan yang berkaitan dengan implementasi demokrasi partisipatif di Nantes, diawali pada tahun 1996 ketika Conseil Municipal membagi commune Nantes menjadi 11 bagian wilayah untuk kemudahan penyediaan dan pengelolaan pelayanan publik. Peraturan tersebut juga mengharuskan adanya pembentukan Comité Consultatif de Quartier (CCQ) di setiap bagian wilayah. Selanjutnya pada tahun 2002 pemerintah Perancis memberlakukan Undang-Undang No. 2002-276 yang mengatur tentang penerapan proximity democracy. Undang-undang tersebut menekankan kembali keharusan bagi area perkotaan dengan jumlah populasi lebih dari 80000 jiwa untuk membentuk dewan perwakilan rakyat yang mempunyai peran konsultatif dengan pemerintah kota khususnya di dalam proses penyusunan kebijakan perkotaan. Segera setelah disahkannya undang-undang tersebut, Pemerintah Kota Nantes merespon dengan peraturan tertanggal 28 Juni 2002 yang menyatakan bahwa CCQ terbuka untuk warga dan organisasi. Namun, wewenang CCQ pada saat itu hanya berada pada tataran konsultatif dan tidak memberikan pengaruh yang besar pada pengambilan keputusan publik.

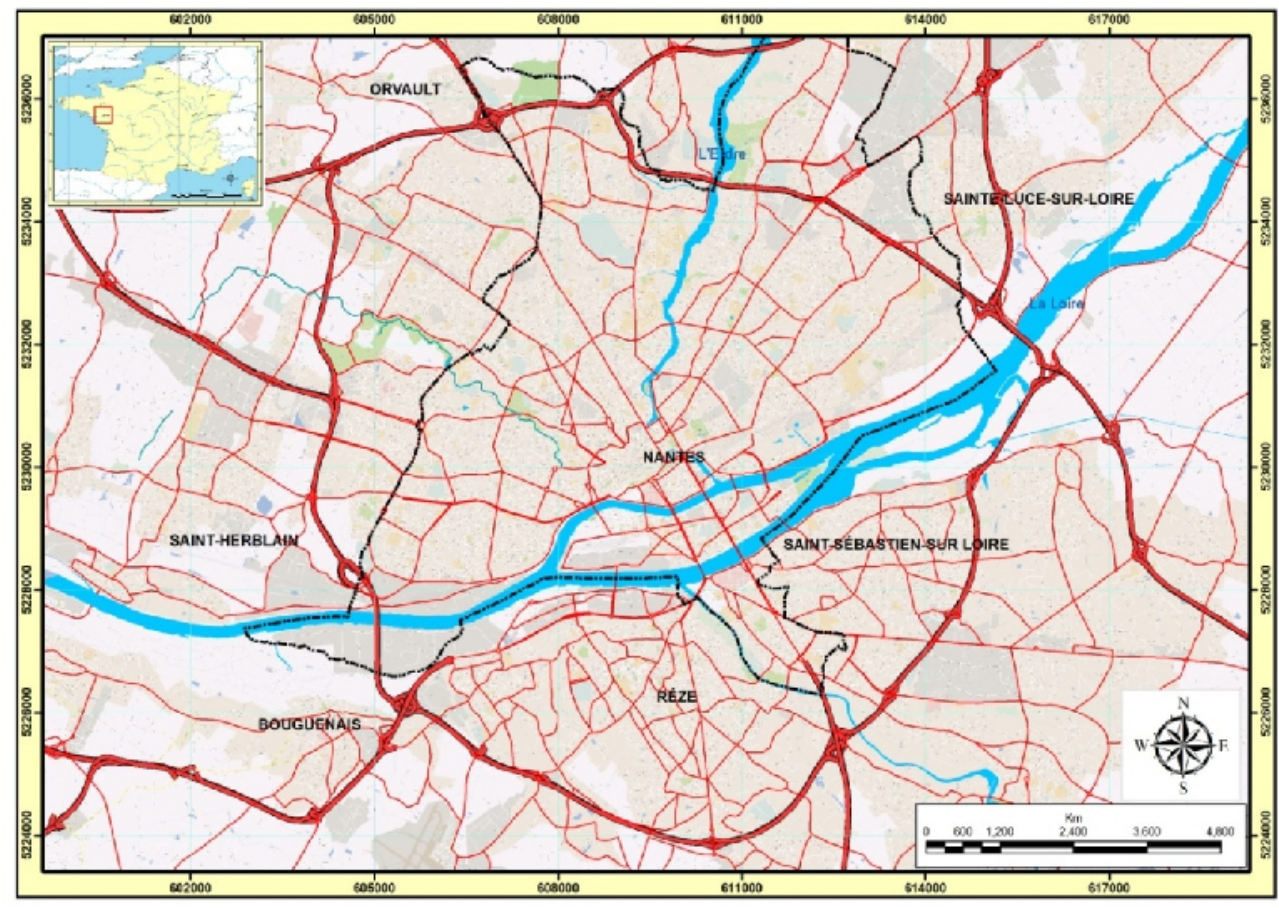

Sumber: Google Street + ESRI ${ }^{(B)} \operatorname{ArCMAP} 9.3$

GAMBAR 3

PETA NANTES DAN AREA URBAN DI SEKITARNYA 
Pada tahun 2009, Nantes mulai meningkatkan upaya untuk mewujudkan gagasan baru dengan meningkatkan peran dewan perwakilan. Fungsi CCQ digantikan oleh Conseil de Quartier (CQ) dengan menegaskan fungsi dan peran CQ sebagai mediator yang merepresentasikan komitmen Nantes untuk warganya. CQ terbentuk dari unsur masyarakat dan mempunyai masa jabatan selama 2 tahun. Untuk dua periode pertama yaitu 2010-2014 Nantes berkeinginan untuk mengubah slogan "hidup bersama" menjadi "bekerja bersama" dengan menekankan pada peran masyarakat. Dengan demikian, keberadaan CQ tidak lagi hanya dalam batas konsultatif tetapi juga sebagai mitra pemerintah dalam penyusunan bersama (coproduction) kebijakan publik.

Bersamaan dengan itu, pemerintah Nantes melaksanakan program Dialogue Citoyen sebagai forum yang mempertemukan pemerintah dengan masyarakat untuk mencari solusi atas permasalahan perkotaan. Sebagai tindak lanjut dari peraturan tersebut, Charte du Dialogue Citoyen (Piagam Dialog Warga) disusun sebagai acuan bersama dalam pelaksanaan program. Piagam ini merupakan hasil pembahasan bersama antara pihak pemerintah kota, dewan perwakilan kota, perwakilan warga dan asosiasi, melalui serangakaian diskusi yang kemudian diadopsi sebagai dokumen resmi oleh Pemerintah Kota pada 29 Januari 2010. Dalam piagam tersebut disebutkan bahwa Dialogue Citoyen adalah sebuah sarana untuk merealisasikan program-program pemerintah daerah secara lebih baik dengan memastikan pelaksanaan yang lebih efektif dan terdistribusi merata, dengan menghormati nilai-nilai keadilan dan solidaritas sosial.

Dokumen ini juga berisi beberapa prinsip dasar, seperti pihak-pihak yang dapat mengikuti forum diskusi dan cakupan materi yang bisa didiskusikan. Dalam dokumen setebal enam halaman tersebut, Nantes juga menyatakan komitmen-komitmen yang harus dipenuhi dalam pelaksanaan program dialog. Komitmen tersebut diantaranya adalah mengutamakan budaya bertukar pendapat dan pemahaman bersama mengenai isu yang dibahas, menjamin bahwa informasi yang diberikan cukup jelas dan dapat dipahami oleh semua partisipan, menjamin adanya sebuah respon resmi dari pemerintah untuk setiap usulan yang dikemukakan oleh warga dari hasil dialog.

\section{Analisis Komparasi}

Berdasarkan proses partisipatif yang diamati di kedua tempat, komparasi dilakukan untuk mengetahui komponen yang mempengaruhi keberhasilan pelaksanaan pendekatan partisipatif yang dilakukan. Berikut ini adalah ringkasan perbandingan kegiatan partisipatif yang dilakukan Peta Hijau di Borobudur dan Dialogue Citoyen di Nantes:

TABEL 1

PERBANDINGAN PETA HIJAU (BOROBUDUR) DAN DIALOGUE CITOYEN (NANTES)

\begin{tabular}{lll} 
Variabel & Peta Hijau & Dialogue Citoyen \\
Kerangka kerja & Konsep pembangunan sosial sebagai & - Konsep demokrasi dan egalitas; setiap \\
& bagian dari konteks pembangunan & orang punya kesempatan yang sama \\
& berkelanjutan; memfokuskan pada & untuk berkontribusi dalam penyusunan \\
& pengumpulan data dan informasi & kebijakan \\
& mengenai suatu tempat secara & - Slogan “bekerja bersama”, dengan \\
& langsung, pertukaran wawasan, dan & menyertakan masyarakat sabagai mitra \\
& perubahan persepsi dan perilaku & pemerintah kota dalam perumusan \\
& & kebijakan \\
Tangga partisipasi & Anak tangga ke tujuh [delegasi & Terletak di tangga ke enam \\
\hline
\end{tabular}




\begin{tabular}{|c|c|c|}
\hline Variabel & Peta Hijau & Dialogue Citoyen \\
\hline Arnstein & $\begin{array}{l}\text { wewenang]: Peta Hijau mengajarkan } \\
\text { keahliannya; partisipan mengambil } \\
\text { inisiatif untuk mengikuti kegiatan } \\
\text { pemetaan dan menggunakan hasilnya } \\
\text { untuk rencana desa }\end{array}$ & $\begin{array}{l}\text { [partnership]: ada kerjasama antara } \\
\text { pengambil keputusan dan warga baik } \\
\text { secara individu maupun organisasi dalam } \\
\text { pengambilan keputusan }\end{array}$ \\
\hline $\begin{array}{l}\text { Kemauan } \\
\text { masyarakat }\end{array}$ & $\begin{array}{l}\text { Kepala Desa meminta Peta Hijau untuk } \\
\text { mengikutsertakan para pemuda dalam } \\
\text { kegiatan pemetaan }\end{array}$ & $\begin{array}{l}\text { Partisipan adalah kombinasi dari } \\
\text { masyarakat yang mendaftar secara suka } \\
\text { rela, perwakilan asosiasi, dan } \\
\text { masyarakat yang dipilih dari daftar } \\
\text { pemilih }\end{array}$ \\
\hline $\begin{array}{l}\text { Kapasitas sumber } \\
\text { daya manusia }\end{array}$ & $\begin{array}{l}\text { Para pemuda yang terlibat sama sekali } \\
\text { tidak memiliki keahlian memeta dan } \\
\text { mempunyai informasi yang relatif } \\
\text { sedikit mengenai area yang dipetakan }\end{array}$ & $\begin{array}{l}\text { Sebagian besar partisipan tampak } \\
\text { memiliki kemampuan komunikasi yang } \\
\text { baik dan mengetahui isu-isu perkotaan }\end{array}$ \\
\hline $\begin{array}{l}\text { Pengalaman } \\
\text { pelaksanaan } \\
\text { partisipasi } \\
\text { sebelumnya }\end{array}$ & $\begin{array}{l}\text { Partisipan tidak memiliki pengalaman } \\
\text { sebelumnya dalam mengikuti kegiatan } \\
\text { partisipatif }\end{array}$ & $\begin{array}{l}\text { Partisipan merupakan kombinasi dari } \\
\text { masyarakat yang pernah terlibat pada } \\
\text { periode jabatan Conseil de Quartier yang } \\
\text { pertama dan yang baru pertama kali } \\
\text { mengikuti lokakarya }\end{array}$ \\
\hline $\begin{array}{l}\text { Kepercayaan } \\
\text { masyarakat }\end{array}$ & $\begin{array}{l}\text { Partisipan mempunyai kepercayaan } \\
\text { yang tinggi kepada Peta Hijau dan juga } \\
\text { mengagumi komitmen para } \\
\text { anggotanya }\end{array}$ & $\begin{array}{l}\text { Partisipan mempunyai kepercayaan yang } \\
\text { tinggi karena adanya jaminan bahwa } \\
\text { aspirasinya dipertimbangkan dan } \\
\text { direspon dengan dokumen resmi }\end{array}$ \\
\hline $\begin{array}{l}\text { Pertukaran } \\
\text { wawasan dan } \\
\text { informasi }\end{array}$ & $\begin{array}{l}\text { Proyek pemetaan dilakukan dari nol } \\
\text { dengan melakukan 2-4 kali lokakarya } \\
\text { pemetaan di awal proses. } \\
\text { Masyarakat, baik yang terlibat sebagai } \\
\text { pemeta maupun tidak, memberikan } \\
\text { informasi berkaitan dengan wilayahnya } \\
\text { dan sebaliknya Peta Hijau memberikan } \\
\text { perspektif dan keahliannya. }\end{array}$ & $\begin{array}{l}\text { Pertemuan-pertemuan lokakarya diawali } \\
\text { dengan penjelasan mengenai konteks } \\
\text { materi yang akan dibahas serta prosedur } \\
\text { pelaksanaan diskusi. Dalam proses } \\
\text { lokakarya, pihak yang bertanggung jawab } \\
\text { memberikan arahan dan bantuan } \\
\text { partisipan tampak susah memahami } \\
\text { materi dan instruksi yang diberikan. }\end{array}$ \\
\hline $\begin{array}{l}\text { Sarana/ teknik } \\
\text { yang digunakan }\end{array}$ & $\begin{array}{l}\text { - Peta dan ikon global } \\
\text { - Observasi langsung ke lokasi } \\
\text { - Wawancara dengan warga lokal dan } \\
\text { tokoh } \\
\text { - Diskusi dan tukar pendapat }\end{array}$ & $\begin{array}{l}\text { Teknik yang digunakan bergantung pada } \\
\text { materi lokakarya, secara umum adalah: } \\
\text { - Diskusi panel } \\
\text { - Observasi langsung ke lokasi } \\
\text { - Pemetaan } \\
\text { - Kuesioner }\end{array}$ \\
\hline $\begin{array}{l}\text { Kompetensi dan } \\
\text { keahlian institusi/ } \\
\text { organisasi } \\
\text { pelaksana }\end{array}$ & $\begin{array}{l}\text { Komunitas mempunyai kompetensi } \\
\text { yang bagus dalam pemetaan, namun } \\
\text { tidak memiliki keahlian spesifik untuk } \\
\text { komunikasi baik dalam hal komunikasi } \\
\text { massa maupun untuk kepentingan } \\
\text { marketing. Hal tersebut memperkecil } \\
\text { peluang untuk menemukan partner } \\
\text { kerjasama/ sponsor dan juga } \\
\text { memasarkan hasil pemetaan secara } \\
\text { komersial }\end{array}$ & $\begin{array}{l}\text { Pejabat yang berwenang mempunyai } \\
\text { kompetensi yang terbatas dalam } \\
\text { memandu dialog dengan warga. Namun } \\
\text { mereka bekerja sama dengan pihak luar } \\
\text { yang merupakan ahli di bidang } \\
\text { komunikasi sosial. Selain itu, pemerintah } \\
\text { Nantes juga terus mengupayakan } \\
\text { peningkatan kompetensi melalui } \\
\text { pelatihan untuk pegawai. }\end{array}$ \\
\hline
\end{tabular}




\begin{tabular}{|c|c|c|}
\hline Variabel & Peta Hijau & Dialogue Citoyen \\
\hline $\begin{array}{l}\text { Komitmen } \\
\text { institusi/ } \\
\text { organisasi } \\
\text { pelaksana }\end{array}$ & $\begin{array}{l}\text { Anggota Peta Hijau mempunyai } \\
\text { komitmen yang besar terlihat dari } \\
\text { kemauan untuk memandu kegiatan dan } \\
\text { mendampingi masyarakat dari awal } \\
\text { proyek pemetaan hingga selesai } \\
\text { walaupun dilakukan secara sukarela. }\end{array}$ & $\begin{array}{l}\text { Seluruh stakeholder kunci yang ditemui } \\
\text { dalam wawancara menunjukkan } \\
\text { komitmen yang tinggi dan merasa } \\
\text { bertanggung jawab atas pelaksanaan } \\
\text { Dialogue Citoyen, walaupun sebagian } \\
\text { besar kegiatan diadakan di luar jam kerja. } \\
\text { Mereka sangat mengapresiasi kehadiran } \\
\text { masyarakat untuk terlibat secara cuma- } \\
\text { cuma untuk bekerja bersama dengan } \\
\text { Kota Nantes }\end{array}$ \\
\hline Pengalaman kerja & $\begin{array}{l}\text { Peta Hijau Yogyakarta telah } \\
\text { mengadakan kegiatan pemetaan } \\
\text { dengan melibatkan masyarakat sejak } \\
\text { tahun } 2002\end{array}$ & $\begin{array}{l}\text { Program Dialogue Citoyen secara resmi } \\
\text { dimulai pada tahun } 2009 \text { dan saat ini } \\
\text { memasuki periode kepemimpinan kedua } \\
2012-2014\end{array}$ \\
\hline $\begin{array}{l}\text { Dukungan } \\
\text { finansial }\end{array}$ & $\begin{array}{l}\text { Kemampuan anggota komunitas dan } \\
\text { masyarakat lokal yang ingin membantu } \\
\text { (seringkali dalam bentuk perlengkapan, } \\
\text { bahan makanan, ruang bekerja) }\end{array}$ & Anggaran keuangan pemerintah daerah \\
\hline Transparansi & $\begin{array}{l}\text { Seluruh tahap pemetaan, mulai dari } \\
\text { fase persiapan hingga penyusunan } \\
\text { rekomendasi dan desain cetak } \\
\text { dilakukan bersama/ oleh masyarakat } \\
\text { sehingga tidak ada celah untuk } \\
\text { memanipulasi informasi }\end{array}$ & $\begin{array}{l}\text { Pendapat masyarakat didokumentasikan } \\
\text { dan dipresentasikan ke dewan kota serta } \\
\text { mendapatkan tanggapan resmi dari } \\
\text { pemerintah; semua dokumen berkaitan } \\
\text { dengan Dialogue Citoyen bisa diperoleh di } \\
\text { situs internet }\end{array}$ \\
\hline $\begin{array}{l}\text { Kejasama dengan } \\
\text { pihak lain }\end{array}$ & $\begin{array}{l}\text { Peta Hijau bekerja hampir selalu hanya } \\
\text { dengan masyarakat dan komunitas } \\
\text { lokal di Borobudur, tanpa bekerja sama } \\
\text { dengan pihak lain }\end{array}$ & $\begin{array}{l}\text { Dialogue Citoyen merupakan sebuah } \\
\text { kebijakan bersama antara Nantes dan } \\
\text { aglomerasi Nantes Métropole. } \\
\text { Dalam pelaksanaannya melibatkan } \\
\text { masyarakat, organisasi, dan Conseil de } \\
\text { Quartier. Untuk merealisasikan usulan } \\
\text { program pembangunan yang disetujui, } \\
\text { dilakukan kerja sama dengan dinas } \\
\text { terkait. }\end{array}$ \\
\hline
\end{tabular}

*Keterangan: kuning = kekurangan, abu-abu = netral, hijau = kelebihan

\section{ANALISIS PREFERENSI TINGGAL PENDUDUK PADA KAWASAN SEKITAR KAMPUS UNDIP TEMBALANG}

Sering kali berkembangnya suatu kawasan menjadi pusat pertumbuhan baru justru tidak disadari atau diantisipasi dan sering dikenal sebagai perkembangan yang tidak terencana, seperti yang dikatakan oleh Evers (1986, dalam Warsono, 2006). Kepadatan permukiman juga berkorelasi dan saling berkaitan dengan perkembangan di kawasan pusat pertumbuhan baru tersebut. Yunus (2008) berpendapat bahwa keterbatasan ruang perkotaan yang sifatnya statis menyebabkan terjadinya alternatif-alternatif dalam mencari kebutuhan ruang untuk tempat tinggal dan akan merambah pada lahan-lahan di luar pusat kota sehingga membentuk suatu konsentrasi baru. 
Dari hasil analisis yang telah dilakukan dari informasi yang diperoleh, didapatkan beberapa alasan tinggal warga di kawasan sekitar Kampus UNDIP Tembalang, yaitu antara lain karena alasan keturunan asli, karena direlokasi UNDIP, karena adanya peluang usaha, serta alasan kenyamanan lokasi dan kondisi alam yang mendukung. Dari berbagai alasan tersebut dapat dikatakan bahwa secara keseluruhan penduduk yang tinggal di sana berpreferensi untuk menetap karena memiliki harapan atau visualisasi jangka panjang akan tempat tinggal dan kehidupan mereka.

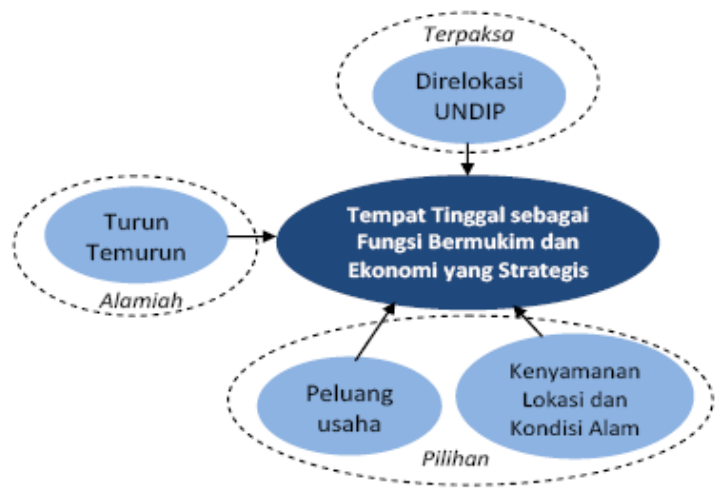

Sumber: Hasil Analisis Penyusun, 2012

\section{GAMBAR 4 \\ PREFERENSI TINGGAL MASYARAKAT DI KAWASAN SEKITAR KAMPUS UNDIP TEMBALANG}

Berdasarkan ilustrasi bagan di atas, dapat dijelaskan bahwa preferensi tinggal masyarakat di kawasan sekitar Kampus UNDIP Tembalang dapat dikelompokkan ke dalam tiga kelompok. Alasan tinggal karena turun temurun sebagai warga asli memang lebih disebabkan karena alasan alamiah. Lalu alasan tinggal karena direlokasi UNDIP merupakan alasan yang dapat dikatakan sebagai sesuatu yang terpaksa dari lingkup eksternal karena di luar dari kehendak individu tersebut. Selanjutnya alasan tinggal yang disebabkan ketertarikan oleh adanya peluang usaha serta kenyamanan lokasi dan kondisi alam dapat dikelompokkan sebagai alasan yang muncul dari pilihan seseorang atau keluarga terhadap lokasi tinggalnya tersebut.

Tidak semua orang berpikiran dalam mencari tempat tinggal adalah sekaligus untuk kepentingan ekonomi mereka, yang maksudnya bahwa rumah atau tempat tinggal biasanya hanya dipandang sebagai tempat istirahat. Masyarakat yang memilih untuk tinggal di kawasan sekitar Kampus UNDIP Tembalang memahami bahwa dengan tinggal atau menetap di sana, tempat tinggal mereka tidak sekedar menjadi tempat istirahat, ada peluang ekonomi yang bisa mereka manfaatkan ataupun tidak. Bayangan atau harapan mereka dengan tinggal di kawasan yang memiliki potensi ekonomi yang besar, didukung dengan kestabilan kondisi alam yang lebih memberi sekuritas bagi tempat tinggal dan atau sekaligus tempat usaha mereka ke depannya, mereka dapat menempati tempat tinggal mereka sekarang ini dalam jangka panjang.

\section{KESIMPULAN}

Berdasarkan eksplorasi yang dilakukan, dapat ditarik kesimpulan bahwa hal-hal non teknis seperti transparansi, komitmen pelaksana, dan kepercayaan masyarakat berperan penting dalam menentukan keberhasilan proses partisipatif. Keberadaan komunitas Peta Hijau dengan 
dedikasi dan komitmennya memungkinkan mereka untuk mendapatkan kepercayaan dari warga di Borobudur walaupun dengan kondisi sumber daya finansial yang sangat terbatas. Demikian juga Nantes yang memberikan jaminan adanya tanggapan resmi dari pemerintah untuk setiap usulan dari lokakarya warga. Sayangnya, situasi di Indonesia secara umum mengindikasikan bahwa pihak pemerintah, sebagai pengambil keputusan, tampak kurang mempunyai komitmen yang kuat untuk menerapkan partisipasi masyarakat yang sebenarnya. Terdapat indikasi bahwa perkembangan penerapan partisipasi masyarakat dalam perencanaan berjalan lamban. Setelah 10 tahun pelaksanaan Musrenbang sebagai alat partisipatif dalam perencanaan pembangunan, inovasi yang dilakukan dalam pelaksanaannya sangat minim, terlepas dari banyaknya kritik yang diterima.

Penggunaan teknik tertentu untuk memandu dialog dengan partisipan juga perlu ditentukan sesuai dengan tujuan yang ingin dicapai dalam program lokakarya. Seringkali, semakin kompleks dan semakin banyak upaya yang perlu dilakukan maka akan semakin lama waktu yang dibutuhkan, tetapi akan mendapatkan hasil yang lebih baik. Green Map, dengan caranya memetakan potensi dan permasalahan menggunakan simbol diketahui dapat menimbulkan ketertarikan warga karena merupakan keahlian baru yang inovatif. Namun, prosesnya membutuhkan waktu yang lama, harus dilakukan dengan pelatihan atau lokakarya pemetaan dan juga peningkatan kesadaran dan pengetahuan tentang isu-isu pembangunan berkelanjutan sehingga partisipan memahami dapat memahami rangkaian kegiatan secara keseluruhan dalam dimensi "keberlanjutan". Sementara Dialogue Citoyen berupaya mengembangkan keragaman teknik untuk berkomunikasi untuk menghidupkan dinamisasi berdiskusi seperti penggunaan peta atau kerjasama dengan ahli komunikasi massa untuk memfasilitasi proses dialog. Sebaliknya, pelaksanaan Musrenbang bertahan tanpa ada perubahan signifikan selama 9 tahun dengan metode yang sama yaitu mediasi melalui presentasi dan penyusunan skala prioritas. Kelebihan dari hal tersebut adalah waktu yang diperlukan tidak terlalu lama dan penerapannya yang tidak terlalu kompleks. Meskipun demikian, cara tersebut tidak benar-benar menghidupkan proses bertukar pendapat dan pengetahuan yang merupakan komponen inti dari konsep partisipasi masyarakat.

Selanjutnya kita juga dapat mengamati bahwa apresiasi terhadap peraturan masih menjadi isu di Indonesia. Terdapat perbedaan antara apa yang dimuat di dalam ketentuan legislasi dengan kenyataan di lapangan. Didasarkan pada peraturan, program Musrenbang seharusnya dapat dikategorikan berada pada tahap konsultatif dengan keterlibatan masyarakat untuk ikut berkontribusi. Namun, beberapa publikasi yang dikaji mengindikasikan adanya manipulasi dalam proses yang dilakukan yang bisa terjadi di setiap level administratif terendah hingga yang tertinggi. Berdasarkan pengalaman yang diambil di Nantes, Indonesia dapat meniru untuk memberikan jaminan adanya respon resmi dari pihak pemerintah untuk setiap usulan yang dihasilkan dari lokakarya warga. Adanya dokumentasi untuk pendapat warga dan respon pemerintah serta kemudahan akses untuk dokumentasi tersebut selain dapat menghilangkan skeptisme, dan menumbuhkan kepercayaan masyarakat, juga akan memudahkan proses evaluasi dan pengawasan terhadap proses yang dilakukan paska dialog.

Pada akhirnya sangat penting bagi seluruh pihak yang terlibat, khususnya pemegang otoritas yang berwenang, untuk dapat memahami dan mendefinisikan kembali makna sebenarnya dari "partisipasi masyarakat". Hal tersebut merupakan tahapan penting yang harus dilakukan agar dalam tahap penyusunan peraturan, persiapan program, maupun pelaksanaannya benar-benar dapat mereprensentasikan tujuan dari pelibatan masyarakat dalam proses perencanaan. 


\section{DAFTAR PUSTAKA}

August, Francois. 2009. Une nouvelle démocratie participative p 122 - 125 dalam TOURNON, Jean-Pierre, dir., La république anti participative: Les obstacles à la participation des citoyens à la démocratie locale. Paris: L'Harmattan.

Andre, Pierre, Martin P., Lanmafankpotin G., 2012. Citizen Participation. Encyclopedic Dictionary of Public Administration.

Baker, Susan. 2006. Sustainable Development. New York: Routledge.

Chauduri, Jayasri Ray. 2001. An Introduction to Development and Regional Planning. Kolkata: Orient Longman Ltd.

Ergazakis, K., Metaxiotis, K. et Psarras, J. dalam Goldberg Michal, Pasher Edna, Levin-Sagi Maya. 2004. Citizen participation in decision-making processes: knowledge sharing in knowledge cities. Journal of knowledge management vol. 10 n॰ 5 2006: $92-98$.

Glasson, John dan Marshall Tim. 2007. Regional Planning. Oxfordshire: Routledge. Hall, Peter. 1992. Urban and Regional Planning, Third Edition. New York: Routledge.

Hemmati, Minu et al. 2007. Participatory Dialogue: Towards a Stable, Safe and Just Society for All. New United Nations Publications. http://www.un.org/esa/socdev/publications/prtcptry_dlg (full_version).pdf.

Le Galic, Mathias. 2004. La Democratie Participative : Le cas nantais. Paris: L'Harmattan

Marshall, Catherine et Rossman, Gretchen B., dalam Schneider, Daniel K. 2007. Méthodes qualitatives en sciences sociales: Petite introduction aux méthodes qualitatives. Version 0.9 http://tecfa.unige.ch/guides/methodo/quali.

Verdier, Philippe. 2009. Le Projet Urbain Participatif; Apprendre à faire la ville avec ses habitants. Edition Adels et Yves Michel. 